\title{
PEMBENTUKAN KOSAKATA BARU SEBAGAI BENTUK COINAGE DALAM MEDIA SOSIAL INSTAGRAM
}

\author{
Kartika Tiara Syarifuddin ${ }^{1}$, Abdul Hafid ${ }^{2}$ \\ Program Studi Pendidikan Bahasa Indonesia \\ Universitas Pendidikan Muhammadiyah Sorong ${ }^{1,2}$ \\ kartikatiarataemim@gmail.com ${ }^{1}$
}

Submit, 28-11-2018 Accepted, 24-12-2018 Publish, 25-12-2018

\begin{abstract}
ABSTRAK
Penelitian ini bertujuan untuk mendeskripsikan proses pembentukan kosakata baru sebagai bentuk coinage pada hashtag dari sudut pandang proses adopsi dan proses adaptasi yang ada dalam media sosial khususnya Instagram yang saat ini menjadi salah satu media sosial paling aktif digunakan oleh remaja Indonesia. Metode yang digunakan dalam penelitian ini adalah metode deskriptif kualitatif. Teknik pengumpulan data yang digunakan adalah teknik simak catat, sedangkan teknik analisis data yang digunakan adalah teknik analisis data oleh Miles and Huberman (interactive models) yang dimulai dari tahap pengumpulan data (data collection), reduksi data (data reduction), penyajian data (data display), dan verivikasi atau simpulan (conclusion drawing). Penentuan proses pembentukan kosakata baru didasarkan pada proses pembentukan kata (word formation). Berdasalkan hasil penelitian, ditemukan sebanyak 14 data mengalami proses adopsi, dan 6 data yang mengalami proses adaptasi. Simpulan, pada media sosial instagram yang berfokus pada hashtag yang digunakan sebagai bentuk coinage menunjukan bahwa jumlah pembentukan kosakata baru dari proses adopsi terbagi menjadi tujuh jenis adopsi bentuk, makna dan tujuan penggunaannya yaitu, (1) vokal tunggal + dua rangkap, (2) vokal rangkap + dua kata, (3) vokal rangkap + tiga kata, (4) dua kata, (5) tiga kata, (6) akronim, (7) kata utuh + pelesapan kata, sedangkan proses adaptasi terbagi menjadi dua jenis adaptasi makna, ucapan dan kelas kata yaitu, (1) KVK dan KVKV, (2) KKVK + pelesapan kata.
\end{abstract}

Kata Kunci: Coinage, Media Sosial, Instagram.

\begin{abstract}
This study aimed to describe the process of forming a new vocabulary as a form of coinage in the hashtag from the point of view of the adoption process and adaptation processes that existed on social media, especially Instagram, which currently became one of the most active social media used by Indonesian teens. The method used in this study was a qualitative descriptive method. The data collection technique used was the note taking technique, while the data analysis technique used was the data analysis technique by Miles and Huberman (interactive models) which was started from the data collection stage, data reduction, data presentation (data display), and verification or conclusion (conclusion drawing). Determination of the process of forming a new vocabulary was based on the word formation process. Based on the results of the study, it was found that 14 data experienced the adoption process, and 6 data that experienced an adaptation process. Conclusion, on Social media Instagram which was focused on
\end{abstract}


the hashtag used as a coinage form showed that the number of new vocabulary formation from the adoption process was divided into seven types of adoption forms, meanings and purposes of use, (1) single + two double vowels, (2) double vowels + two words, (3) double vowels + three words, (4) two words, (5) three words, (6) acronyms, (7) whole words + word loss, while the adaptation process was divided into two types of meaning adaptations, words and class words namely, (1) KVK and KVKV, (2) KKVK + word dissolution.

Keywords: Coinage, Social Media, Instagram.

\section{PENDAHULUAN}

Bahasa adalah sistem lambang bunyi yang arbitrer yang digunakan oleh para anggota kelompok sosial untuk bekerja sama,berkomunikasi, dan mengidentifikasi diri (Chaer, 2015). Sebagai sarana utama manusia dalam berkomunikasi, bahasa tidak dapat lepas dari manusia. Manusia adalah makhluk sosial yang selalu berinteraksi dan membutuhkan bahasa untuk menyalurkan pemikirannya kepada orang lain. Sejalan dengan ciri bahasa yang beragam, diantaranya bahasa sebagai sistem, lambang, bunyi, arbitrer, kovensional, bervariasi, produktif, universal, unik, dinamis, dan manusiawi.

Selain ciri bahasa, pengguna bahasa dikelompokan berdasarkan usia yaitu anakanak, remaja, dan dewasa. Pada era globalisasi yang terus menerus berkembang dan semakin canggih, remaja berperan penting dalam penggunaan dan penciptaan bahasa. Sumarsono, (2012) menjelaskan bahwa masa remaja ditinjau dari segi perkembangan, merupakan masa kehidupan manusia yang paling menarik dan mengesankan. Hal ini tidak hanya berlaku pada cara hidup remaja, namun juga berdampak pada penggunaan bahasa yang mereka lakukan.

Rasa ingin tahu dan kebebasan berekspresi membuat remaja tidak hanya merombak sturuktur bahasa, tetapi juga dengan kreatifnya menciptakan sebuah bahasa yang hanya dipahami oleh kelompok remaja. Hal ini sejalan dengan pendapat Sumarsono (2012) yang mengatakan salah satu ciri "bahasa" remaja adalah "kreativitas" bahasa yang diciptakan oleh para remaja umumnya bersifat sementara, namun tentu saja akan memberikan dampak cukup besar dalam perkembangan bahasa. Selain penggunaan bahasa yang tidak sesuai, munculnya kosakata baru, pemanipulasian struktur bahasa, banyaknya kosakata aktif yang berubah menjadi pasif dan sebaliknya kosakata pasif yang berubah menjadi aktif, merupakan sederet konsekuensi ketika bahasa remaja lebih mendominasi masyarakat khususnya remaja itu sendiri. 
Banyaknya penciptaan kata yang tidak sesuai aturan dan kaidah, tentunya menarik. Penciptaan kata-kata baru akan memperkaya kosakata bahasa Indonesia khususnya bahasa remaja. Penambahan kosakata baru dan teori-teori baru akan bermunculan seiring dengan munculnya kata-kata baru yang memerlukan tata bahasa yang baru. Sejalan dengan kemampuan tersebut, remaja memerlukan sarana untuk menyalurkan rasa ingin tahu dan kebebasan mereka. Cara tercepat di era globalisasi saat ini adalah media sosial. Media sosial adalah kelompok dari aplikasi berbasiskan internet yang memungkinkan terciptanya website yang interaktif. Media sosial layaknya sebuah perkampungan online dan penggunanya dapat dikatakan sebagai masyarakat online.

Tujuan utama media sosial adalah untuk berbagai informasi. Berbeda dengan artikel di internet, media sosial lebih fokus pada hubungan penggunanya. Media sosial diciptakan untuk mempermudah komunikasi penggunanya dalam berbagi informasi dan kemudahan dalam berkomunikasi tersebut terangkum dalam satu aplikasi yang berbasis internet. Beberapa kelompok aplikasi yang dimaksud adalah Facebook, Twitter, Path, Skype, dan Instagram. Instagram adalah aplikasi photo-sharing dan layanan jejaring sosial online yang memungkinkan penggunanya untuk mengambil gambar atau video, menerapkan filter digital untuk mereka, dan berbagi hasilnya melalui berbagai layanan social media seperti Facebook, Twitter dan situs media lainnya berupa video dan foto yang dibagikan oleh pengguna Instagram dapat disertai dengan caption (status) yang menjelaskan maksud dari foto atau video tersebut. Dalam caption, umumnya kita akan menemukan tagar (tanda pagar) atau sering disebut Hashtag yang biasanya digunakan untuk merujuk pada topik sebuah kiriman.

Penggunaan Hashtag mempermudah seseorang dalam mencari sebuah topik yang sama dalam media sosial khususnya Instagram. Kegiatan, nama tempat, permasalahan atau sebuah kalimat berupa penyemangat maupun belasungkawa dapat dikemas dengan menggunakan Hashtag. Sejalan dengan pendapat Dewi (2015) yang mengatakan bahwa The purpose of the hashtag is to categorize the images and make them searchable.

Penggunaan Hashtag di Instagram membawa kita pada kata-kata baru. Penemuan kata-kata yang bersifat baru khususnya penyandian bahasa Indonesia yang dilahirkan dari bahasa asing (foreign language) yang menjadi ukuran utama dan urgent dalam penelitian ini. Pembentukan kosakata baru yang berasal dari kosakata bahasa 
asing banyak ditemukan dalam posting-anstatus remaja Indonesia dalam bentuk Hashtag. Penggunaan Hashtag pada status remaja Indonesia berasal dari kosakata bahasa asing yang kemudian dibentuk menjadi kosakata baru dengan pelafalan bahasa Indonesia. Penyesuaian ini harus diikuti oleh pembentukan kata yang diadopsi atau diadaptasi dari bahasa asing sebagai bentuk coinage-nya. Pembahasan tentang pembentukan kata (coinage), ilmu yang dengan fasih membahas hal tersebut adalah morfologi.

Chaer (2015) mengatakan bahwa morfologi berarti ilmu mengenai bentukbentuk dan pembentukan kata. Proses pembentukan kata terjadi karena manusia selalu bereksperimen dan memiliki sifat dinamis, selalu berusaha untuk menemukan maupun menciptakan hal-hal baru dan kata tak luput dari itu. Pembentukan kosakata baru terjadi karena ditemukannya hal baru. Hal baru tersebut dapat berbentuk fenomena, kegiatan, hewan, tumbuhan dan lain sebagainya. Proses pembentukan kosakata baru yang berasal dari bahasa asing akan mengalami penyesuaian baik dari penulisan, susunan, bahkan pengucapan. Dalam ilmu morfologi, terdapat kajian yang khusus membahas tentang penyerapan (adopsi, adaptasi, penerjemahan) dan perubahan bunyi sebagai dampak dari perubahan bentuk penulisan atau morfofonemik.

Penelitian tentang pembentukan kata dengan menggunakan media sosial sebagai subjek penelitiannya pernah dilkukan oleh Dewi dari Universitas Udayana (2015) yang berjudul Type Of Word Formations On Instagram Hashtags. Hasil penelitian yang dilakukan oleh Dewi meliputi klasifikasi dan deskripsi tipe-tipe pembentukan kata yang membentuk tanda pagar di Instagram serta menentukan makna yang terkandung dalam istilah tersebut. Persamaan penelitian yang dilakukan oleh Dewi dengan penelitian ini, yaitu sama-sama mendeskripsikan pembentukan kata pada Hashtag yang ditemukan di Instagram. Perbedaannya terletak pada fokus penelitian. Penelitian yang dilakukan Dewi berfokus pada pembentukan kata yang ditemukan pada Hashtag yang ada di Instagram secara keseluruhan, sedangkan dalam penelitianini berfokus pada konsep pembentukan kosakata bahasa Indonesia dari kosakata bahasa asing yang ditemukan pada Hashtag di Instagram.

Penelitian selanjutnya dilakukan oleh Jacobs dari Universitas Sam Ratulangi (2013) yang berjudul Penggunaan Pembentukan Kata Bahasa Inggris dalam Facebook. Penelitian ini menggunakan media sosial Facebook sebagai subjek kajian dan hasil 
penelitian yang dilakukan berupa penemuan pembentukan bahasa Inggris yang sering digunakan pengguna Facebook dalam menulis status, berkomentar maupun dalam percakapan melalui chatroom. Persamaan penelitian yang dilakukan oleh Jacobs dengan penelitian ini yaitu sama-sama menjadikan pembentukan kata bahasa Inggris sebagai kajian penelitian. Perbedaannya terletak pada fokus penelitian. Penelitian yang dilakukan oleh Jacobs berfokus pada pembentukan kata bahasa Inggris secara menyeluruh yang ditemukan dalam status, komentar juga chatroom, dan data tersebut berasal dari media sosial Facebook, sedangkan dalam penelitian ini berfokus pada pembentukan kosakata baru bahasa Indonesia yang diambil dari kosakata bahasa Inggris berupa Hashtag yang berasal dari media sosial Instagram.

\section{METODE PENELITIAN}

Metode dalam penelitian ini menggunakan metode deskriptif kualitatif. Data dalam penelitian ini disajikan dalam bentuk paparan data Hashtag yang sesuai dengan tujuan penelitian.Sumber data penelitian adalah media sosial Instagram. Data penelitian berupa Hashtag yang ada di media sosial Instagram.Teknik pengumpulan data yang digunakan adalah teknik dokumentasi. Data yang sesuai dengan indikator penelitian diambil dengan carascreenshoot. Teknik analisis data yang digunakan adalah teknik analisis data interactive model. Langkah-langkah analisis data meliputi: (1) mengumpulkan semua data Hashtag yang sesuai dengan indikator yang telah ditentukan, (2) pengumpulan data, (3) penyajian data, (4) reduksi data, (4) pengkodean data, (5) penafsiran data, (6) penarikan kesimpulan.

\section{HASIL PENELITIAN}

Penelitian ini difokuskan pada pembentukan kosakata baru dalam bahasa Indonesia yang berasal dari bahasa asing yang digunakan pada Hashtag di media sosial Instagram melalui proses adopsi dan adaptasi yang dilakukan oleh remaja Indonesia. Hasil penelitian ini ditemukan sebanyak 14 data mengalami proses adopsi, dan sebanyak 6 data mengalami proses adaptasi.

Proses adopsi adalah proses pengambilan kata yang diambil oleh sebuah bahasa namun tetap sama seperti bahasa asalnya. Proses adopsi seringkali terjadi pada bentuk penulisan dan artinya, dan terdapat pula data yang perubahannya hanya terjadi pada 
penulisannya. Proses pembentukan kosakata baru secara adopsi melalui bahasa asing yang dilakukan oleh remaja Indonesia pada media sosial Instagram dalam bentuk Hashtag dijabarkan berdasarkan kaidah-kaidah pembentukan kata (word formation) yang ada dalam bahasa Indonesia. Ditemukan sebanyak 14 data Hashtag yang tergolong dalam proses adopsi yaitu \#Instagood, \#Instapic, \#Instafood, \#Instamood, \#Instacool, \#Instadailypic, \#Instago, \#typo, \#qotd, \#diy, \#fyi, \#Olshop, \#rotfl, dan \#imho. Proses adopsi berdasarkan 14 data tersebut, dibagi menjadi 7 proses yaitu, (1) vokal tunggal + dua rangkap, (2) vokal rangkap + dua kata, (3) vokal rangkap + tiga kata, (4) dua kata, (5) tiga kata, (6) akronim, (7) kata utuh + pelesapan kata.

Proses adaptasi adalah proses pemungutan suatu kata dari bahasa daerah atau bahasa asing dengan menyesuaikan pelafalan maupun kaidah dan penulisannya dengan kaidah bahasa Indonesia. Proses adaptasi sering kali terjadi pada bentuk pengucapan dan arti, terdapat pula proses adapatasi yang hanya terjadi pada bentuk pengucapannya saja. Proses pembentukan kosakata baru secara adaptasi melalui bahasa asing yang dilakukan oleh remaja Indonesia pada media sosial Instagram dalam bentuk Hashtag dijabarkan berdasarkan kaidah-kaidah pembentukan kata (word formation) yang ada dalam bahasa Indonesia. Ditemukan sebanyak 6 data Hashtag yang tergolong dalam proses adaptasi yaitu, \#rip, \#lol, \#yolo, \#swag, \#kepo, dan \#pap. Proses adaptasi berdasarkan 6 data tersebut, dibagi menjadi 2 proses yaitu, (1) KVK dan KVKV, (2) $\mathrm{KKVK}+$ pelesapan kata.

\section{PEMBAHASAN}

Penelitian ini berfokus pada pembentukan kosakata baru sebagai bentuk coinage yang ada dalam media sosial Instagram berupa data Hashtag yang disesuaikan dengan indikator penelitian. Berikut adalah penjelasan mengenai hasil analisis data.

\section{Adopsi Bentuk, Makna, dan Tujuan Penggunaan (Vokal Tunggal + Dua Kata) \#Instago}

Tahap peminjaman (borrowing) yaitu pengambilan bahasa dari bahasa lain. Peminjaman yang terjadi pada \#Instago mengalami 2 proses perubahan bunyi yaitu aferesis, dan apokop. Proses aferesis dapat terlihat ketika huruf /e/ pada awal kata $\left[{ }^{\mathrm{e}}\right.$ Instago $\left.{ }^{\mathrm{w}}\right]$ ditanggalkan sehingga menjadi $\left[\operatorname{Instago}^{\mathrm{w}}\right]$. Proses apokop dapat terlihat ketika bunyi /w/ pada [Instago ${ }^{\mathrm{w}}$ ] ditanggalkan sehingga menjadi [Instago]. 
Proses terjemahan pinjaman pada\#Instago memiliki makna "foto atau video perjalanan yang diunggah di Instagram" dan tidak mengalami perubahan makna dan tujuan penggunaanya ketika digunakan dalam bahasa Indonesia. Tidak terjadinya perubahan makan sebab \#Instago memiliki makna asosiatif yang ketika diciptakan telah ditentukan konsep dan tujuan pengunaannya. Makna asosiatif adalah makna yang dimiliki sebuah kata berkenaan dengan hubungan kata itu dengan sesuatu yang berada di luar bahasa (Chaer, 2015). Makna asosiatif pada \#Instago menandakan bahwa \#Instago hanya dapat digunakan di sosial media Instagram, dan khusus membahas tentang foto ataupun video terunggah tentang perjalanan seseorang.

Pada tahap pemajemukan, penjabaran \#Instago sebagai berikut: $\left[\frac{\text { Instant }}{1}+\frac{G o}{2}\right]$. Instant bermakna seketika. Dalam hal ini, Instantpada dasarnya merupakan bagian dari kata Instagram, namun pada kenyataannya Instagram adalah gabungan dari kata Instant dan Telegram. Jadi Insta dalam \#Instago tidak diambil dari kata Instagram, melainkan diambil dari kata Instant; Go bermakna pergi. Proses compounding terletak pada penyatuan makna [1] dan [2] menjadi lebih sempit (penyempitan makna), yang pada makna harfiahnya adalah "seketika pergi" berubah menjadi "foto atau video perjalanan yang diunggah di Instagram".

Tahap pemotongan (clipping) yaitu adalah proses pembentukan kata di mana sebuah kata dikurangi atau diperpendek tanpa merubah makan asli dari kata tersebut (Zubaidah, 2015). Pada tahap pemotongan, \#Instago mengalami proses pemotongan. Proses clipping terjadi pada kata/Insta/ yang merupakan hasil pemotongan satu suku kata dari /Instant/ mengalami pemotongan pada huruf /n/ dan /t/ menjadi /Insta/, sedangkan / Go/ tidak mengalami proses pemotongan. Kata / Go/ tidak mengalami proses pemotongan karenavokal /o/ yang terletak di akhir kata, selain itu kata /Go/ hanya terdiri dari dua huruf dan satu suku kata. Ketika huruf /G/ dan /O/ dipisah, dan digabungkan dengan /Insta/ akan memunculkan makna yang berbeda dan tidak sesuai dengan tujuan awal kata tersebut dibuat. Misalnya menjadi [Instag] atau [Instao]. [Instag] atau [Instao] masih dapat dibaca dengan mudah, namun artinya menjadi tidak jelas dan dari segi pengucapannya tidak menimbulkan kesan menarik.

Pada tahap penggabungan, \#Instago merupakan gabungan dari dua suku kata dari sebuah kata dan satu kata utuh. Dua suku kata yang dimaksud adalah /Insta/ yang 
merupakan dua suku kata awal dari kata /Instant/, lalu digabungkan dengan satu kata utuh yaitu /Go/ menjadi [Instago].

\section{Adopsi Bentuk, Makna, dan Tujuan Penggunaan (Vokal Rangkap + Dua Kata) \#Instacool}

Peminjaman pada \#Instacool mengalami 4 proses yaitu aferesis, sinkop, netralisasi dan monoftongisasi. Proses aferesis terlihat ketika huruf /e/ pada awal kata [ ${ }^{\mathrm{e}}$ Insta ${ }^{\mathrm{e}}$ cool] ditanggalkan sehingga menjadi [ $\operatorname{Insta}^{\mathrm{e}}$ cool]. Proses sinkop terlihat ketika bunyi /e/ yang terletak ditengah kata [ $\left.\operatorname{Insta}^{\mathrm{e}}{ }^{-} \mathrm{cool}\right]$ dihilangkan sehingga menjadi [Instacool].Proses netralisasi terlihat ketika huruf /c/ dilafalkan seperti huruf /k/ akibat dari vokal rangkap yang ada dibelakang [Instacool] menjadi [Instak ${ }^{\mathrm{k}}$ ool]. Proses monoftongisasi, terlihat ketika vokal rangkap /oo/ pada [Insta ${ }^{\mathrm{k}} \underline{\text { ool] }}$ berubah menjadi monoftong /u/ akibat dari proses monoftongisasi, maka pelafalannya menjadi [Insta ${ }^{\mathrm{ku}} 1$ ].

\#Instacool memiliki makna "hal mengagumkan yang diunggah di Instagram" dan tidak mengalami perubahan makna ketika digunakan dalam bahasa Indonesia, sebab \#Instacool memiliki makna asosiatif yang ketika diciptakan telah ditentukan konsep dan tujuan pengunaannya. Makna asosiatif adalah makna yang dimiliki sebuah kata berkenaan dengan hubungan kata itu dengan sesuatu yang berada di luar bahasa (Chaer, 2015). Makna asosiatif pada \#Instacool menandakan bahwa hanya dapat digunakan di sosial media Instagram saja dan khusus membahas mengenai foto ataupun video terunggah berupa hal yang keren atau menakjubkan menurut subjek penggunannya.

Pada pemajemukan, \#Instacool dapat dijabarkan sebagai berikut: $\left[\frac{\text { Instant }}{1}+\frac{\text { Cool }}{2}\right]$. Instant bermakna seketika, dalam hal ini, Instant merupakan bagian dari kata Instagram, akan kenyataannya Instagram adalah gabungan dari kata Instant dan Telegram. Jadi Insta dalam \#Instamood tidak diambil dari kata Instagram, melainkan diambil dari kata Instant; Cool bermakna menakjubkan. Proses compounding terletak pada penyatuan makna [1] dan [2] menjadi lebih sempit (penyempitan makna), pada makna harfiahnya adalah "seketika mengagumkan" berubah menjadi "hal mengagumkan dalam bentuk foto atau video yang diunggah di Instagram". Maknanya tidak mengalami peberubahan akan tetapi menjadi lebih spesifik karena \#Instacool memiliki makna asosiatif.

Tahap pemotongan (clipping) yaitu kliping adalah proses pembentukan kata di mana sebuah kata dikurangi atau diperpendek tanpa merubah makan asli dari kata tersebut (Zubaidah, 2015). Tahap pemotong pada \#Instacool hanya terjadi pada kata 
/Insta/ yang merupakan hasil pemotongan satu suku kata dari /Instant/, sedangkan /Cool/ tidak mengalami pemotongan. Kata /Cool/ tidak mengalami proses pemotongan sebab adanya vokal rangkap /oo/ yang terletak ditengah kata. Ketika vokal rangkap /oo/ pada /Cool/ dipisah atau dipotong, akan menjadi /co/ dan /ol/ yang jika digabungkan dengan kata /Insta/ akan memunculkan makna yang berbeda dan tidak sesuai dengan tujuan awal kata tersebut dibuat. Misalnya menjadi [Instaco] maupun [Instaol] yang maknanya akan berbeda dengan [Instacool]. \#Instacool merupakan gabungan dua suku kata dari sebuah kata dan satu kata utuh. Dua suku kata tersebut adalah /Insta/ yang merupakan dua suku kata awal dari kata /Instant/, lalu digabungkan dengan satu kata utuh yaitu /Cool/ menjadi [Instacool].

\section{Adopsi Bentuk, Makna, dan Tujuan Penggunaan (Vokal Rangkap + Tiga kata) \#Instadailpic}

Pada tahap peminjaman, \#Instadailypic mengalami 3 proses yaitu aferesis, sinkop dan apokop. Prosesaferesis terlihat ketika huruf /e/ pada awal kata [ ${ }^{\mathrm{e}}$ Insta ${ }^{\mathrm{e}}$ dailypic $\left.{ }^{\mathrm{k}}\right]$ dihilangkan dan menjadi [Insta ${ }^{\mathrm{e}}$ dailypic $\left.{ }^{\mathrm{k}}\right]$. Proses sinkop dalam \#Instadailypic terjadi ketika bunyi /e/ yang terletak ditengah kata [Insta ${ }^{\mathrm{e}}$ dailypic $^{\mathrm{k}}$ ] ditanggalkan menjadi [Instadailypic ${ }^{\mathrm{k}}$ ]. Proses apokop dalam \#Instadailypic terjadi ketika bunyi /c/ pada [Instadailypic $\left.\underline{\mathrm{c}}^{\mathrm{k}}\right]$ ditanggalkan hingga bunyinya menjadi [Instadailypi ${ }^{\mathrm{k}}$ ].

Pada tahap terjemahan pinjaman, \#Instadailypic memiliki makna "gambar tentang keseharian yang diunggah di Instagram" dan tidak mengalami perubahan makna ketika digunakan dalam bahasa Indonesia. Hal ini karena \#Instadailypic memiliki makna asosiatif yang ketika diciptakan telah ditentukan konsep dan tujuan pengunaannya. Makna asosiatif adalah makna yang dimiliki sebuah kata berkenaan dengan hubungan kata itu dengan sesuatu yang berada di luar bahasa (Chaer, 2015). Makna asosiatif pada \#Instadailypic menandakan bahwa hanya dapat digunakan di sosial media Instagram saja dan khusus membahas tentang foto ataupun videoterunggah yang merupakan kegiatan sehari-hari subjek penggunanya.

Pada \#Instadailypic terdiri dari tiga kata dan dapat dijabarkan sebagai berikut:

$\left[\frac{\text { Instant }}{1}+\frac{\text { Daily }}{2}+\frac{\text { Picture }}{2}\right]$. Kata Instant bermakna seketika, namun dalam hal ini, Instantdisangka merupakan bagian dari kata Instagram, namun pada kenyataannya 
Instagram adalah gabungan dari kata Instant dan Telegram. Jadi Insta dalam \#Instadailypic tidak diambil dari kata Instagram, melainkan diambil dari kata Instant; Daily bermakna sehari-hari; Picture bermakna gambar. Proses compounding terletak pada penyatuan makna [1][2][3] menjadi lebih sempit (penyempitan makna). \#Instadailypic memiliki makna harfiah "gambar sehari-hari seketika" lalu mengalami penyempitan makna dan berubah menjadi "gambar tentang keseharian yang diunggah di Instagram".

Proses pemotongan (clipping)yaitu kliping adalah proses pembentukan kata di mana sebuah kata dikurangi atau diperpendek tanpa merubah makan asli dari kata tersebut (Zubaidah, 2015). Tahap pemotongan yang terjadi pada kata/Insta/ yang merupakan hasil pemotongan satu suku kata dari /Instant/, dan kata /Pic/ yang merupakan hasil pemotongan satu suku kata dari /Picture/, sedangkan /Daily/ tidak mengalami pemotongan. Kata /Daily/ tidak mengalami proses pemotongan sebab terdapat vokal rangkap /ai/ yang terletak ditengah kata. Ketika vokal rangkap /ai/ pada /Daily/ dipisah atau dipotong, akan menjadi /da/ atau /ily/ dan jika digabungkan dengan kata/Insta/ akan memunculkan makna yang berbeda dan tidak sesuai dengan tujuan awal kata tersebut dibuat. Misalnya menjadi [Instadapic] maupun [Instailypic] yang maknanya akan berbeda dengan [Instadailypict].

Tahap penggabungan pada \#Instadailypic merupakan gabungan tiga suku kata awalan dari dua buah kata dan satu kata utuh. Dua suku kata awalan yang dimaksud adalah /Instant/ yang diambil dua suku kata awal yaitu /Insta/, dan /Picture/ yang diambil suku kata awalnya yaitu /pic/, lalu digabungkan dengan satu kata utuh yaitu /Daily/ menjadi [Instadailypic].

\section{Adopsi Bentuk, Makna, dan Tujuan Penggunaan (Dua Kata) \\ \#Instapic}

Pada tahap peminjaman, \#Instapic mengalami 3 proses yaitu proses aferesis, sinkop dan apokop. Proses aferesis terjadi ketika bunyi /e/ pada awal kata [ ${ }^{\mathrm{e}} \operatorname{Insta}^{\mathrm{e}} \mathrm{pic}^{\mathrm{k}}$ ] ditangalkan sehingga menjadi [Insta ${ }^{\mathrm{e}} \mathrm{pic}^{\mathrm{k}}$ ]. Proses sinkop terjadi ketika bunyi /e/ yang terletak ditengah kata [Insta ${ }^{\mathrm{e}} \mathrm{pic}^{\mathrm{k}}$ ] dihilangkan sehingga menjadi [Instapic ${ }^{\mathrm{k}}$ ].Proses apokop terjadi ketika bunyi /c/ pada [\#Instapic ${ }^{\mathrm{k}}$ ] dihilangkan sehingga menjadi $\left[\right.$ Instapi $\left.^{\mathrm{k}}\right]$. 
Pada tahap terjemahan pinjaman, \#Instapic dalam bahasa Inggris memiliki makna "gambar instagram" dan ketika digunakan dalam bahasa Indonesia, maknanya tidak berubah dan tetap sama, yaitu "gambar yang diunggah di instagram". Hal tersebut berlaku untuk tujuan penggunaannya, sebab \#Instapic memiliki makna asosiatif yang ketikadiciptakan telah ditentukan konsep dan tujuan pengunaannya. Makna asosiatif adalah makna yang dimiliki sebuah kata berkenaan dengan hubungan kata itu dengan sesuatu yang berada di luar bahasa (Chaer, 2015).

Pada tahap pemajemukan, \#Instapic terdiri dari dua kata dan dapat dijabarkan sebagai berikut: $\left[\frac{\text { Instant }}{1}+\frac{\text { Picture }}{2}\right]$. Instant bermakna seketika, namun dalam hal ini, Instant sebenarnya merupakan bagian dari kata Instagram, akan tetapi jika ditelusuri lebih jauh, Instagram adalah gabungan dari kata Instant dan Telegram. Jadi Insta dalam \#Instapic tidak diambil dari kata Instagram, melainkan diambil dari kata Instant; Picture bermakna gambar. Proses compounding terletak pada proses penyatuan makna [1] dan [2] menjadi lebih sempit atau sering dikenal dengan istilah penyempitan makna. Makna harfiahnya yaitu "gambar yang diunggah seketika" berubah menjadi lebih spesifik dan jelas yaitu "gambar yang diunggah dengan cepat di Instagram".

Pada tahap pemotongan (clipping) proses pembentukan kata di mana sebuah kata dikurangi atau diperpendek tanpa merubah makan asli dari kata tersebut (Zubaidah, 2015). Tahap pemotongan ini, \#Instapic mengalami dua proses pemotongan. Prosesnya adalah sebagai berikut: /Instant/ [1] $\rightarrow$ Insta; /Picture/ [2] $\rightarrow$ Pic yang jika digabungkan mnejadi [Instapic].

Tahap penggabungan pada \#Instapic merupakan hasil penggabungan dari dua suku kata awalan. Pertama adalah /Insta/ yang merupakan awalan dari kata / Instant/, lalu digabungkan dengan suku kata awalan lain dari kata /Picture/ yang menjadi /pic/. Hasil penggabungan dari kedua kata di atas menghasilkan kata baru yang aktif digunakan sebagai Hashtag yaitu /Instapic/.

\section{Adopsi Bentuk, Makna, dan Tujuan Penggunaan (Tiga Kata) \#OLShop}

Pada tahap peminjaman, \#OLShop mengalami 1 proses yaitu proses aferesis. Proses aferesis terlihat ketika bunyi $/ \mathrm{w} /$ pada $\left[\mathrm{O}^{\mathrm{W}} \mathrm{LShop}\right]$ ditanggalkan sehingga menjadi [OLShop]. Penanggalan ini terjadi sebab huruf /O/ dalam bahasa Inggris terdapat bunyi tambahan yaitu bunyi $/ \mathrm{w} /$ setelahnya, menjadi $/ \mathrm{O}^{\mathrm{W}} /$ sedangkan dalam 
bahasa Indonesia huruf /O/ tidak mendapat tambahan bunyi apapun atau disebut dengan bunyi tunggal. Alasan mengapa bunyi /w/ ditanggalkan karena disesuaikan dengan ejaan dalam bahasa Indonesia. Afjalurrahmansyah (2018) transformasi kata serapan dipahami dengan baik untuk menghindari ambiguitas, kekeliruan dan kesalahan dalam menginterpretasi sebuah kata serapan.

Tahap terjemahan pinjaman ini, \#OLShop memiliki makna "toko yang ada di internet" dan ketika digunakan dalam bahasa Indonesia \#OLShop dari segi makna tidak mengalami perubahan arti maupun tujuan penggunaan, hal ini karena \#OLShop memiliki makna asosiatif yang ketika diciptakan telah ditentukan konsep dan tujuan pengunaannya. Makna asosiatif pada \#OLShop membuat pengguna lain ketika melihat Hashtag tersebut langsung memahami bahwa foto atau video yang terunggah membahas mengenai benda yang dijual secara online.

Pada tahap ini, \#OLShop terdiri dari 3 kata yang berbeda dan dapat dijabarkan sebagai berikut: $\left[\frac{O n}{1}+\frac{\text { Line }}{2}+\frac{\text { Shop }}{2}\right]$. On bermakna di; Line bermakna jalur; Shop bermakna toko. Kata $O n$ dan Line semenjak berkembangnya globalisasi secara menyeluruh dan dikenalkannya internet pada dunia terutama media sosial, masyarakat (pengguna internet) sering menggunakan internet dan akhirnya menggabungkan kata $O n$ dan Line menjadi Online yang memiliki arti "dalam jaringan" atau sering diartikan

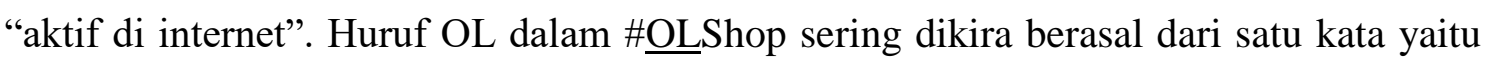
Online, namun sebenarnya kata OL tersebut berasal dari dua kata berbeda yaitu $O n$ dan Line. Pada kenyataanya Online merupakan frasa dari kata On dan Line. Proses compounding terletak pada penyatuan makna [1][2][3] menjadi makna yang lebih sempit yakni "toko yang ada di internet" sebab \#OLShop tidak digunakan untuk menggambarkan toko yang ada di dunia nyata.

Tahap pemotongan (clipping) yaitu proses pembentukan kata di mana sebuah kata dikurangi atau diperpendek tanpa merubah makan asli dari kata tersebut (Zubaidah, 2015). Tahap pemotongan yangterjadipada \#OLShop hanya terjadi pada kata $[O n]$ dan [Line], sedangkan [Shop] tidak mengalami proses pemotongan. Prosesnya adalah sebagai berikut: On [1] $\rightarrow$ /O/; Line[2] $\rightarrow /$ L/; Shop [3] $\rightarrow$ /Shop/. Kata Shop tidak mengalami pemotongan karena [Shop] hanya terdapat satu huruf vokal saja /o/ dan satu suku kata saja. Sedangkan jika dipotong, maka pembagiannya menjadi /Sho/ atau /Op/ atau /S/ dan jika digabungkan dengan OL akan tampak seperti [OLSho] atau [OLop] 
atau [OLS]. Jika dilihat sekilas, ketiga contoh diatas dapat diucapkan seperti sebuah kata, akan tetapi dari segi estetika tidak menarik untuk digunakan, selain itu ketiga bentuk di atas tidak memiliki arti yang jelas, tentu akan membuat pengguna merasa bingung mengenai tujuan dari adanya bentuk diatas. Contohya seperti [OLSho] pengguna akan berfikir itu adalah [OLShock] atau [OLop] yang disangka [OLopen] atau [OLS] yang disangka [OLShow] atau [OLShower] atau bahkan [OLScary]. Ketidakjelasan makna inilah yang dihindari, sehingga kata [Shop] tidak dipotong, hal ini berguna untuk menghindari kesalahan pandangan dalam mengartikan tujuan dari penggunaan \#OLShop tersebut.

Tahap penggabungan pada \#OLShop merupakan gabungan dari awal kata [On] yaitu /O/ dan Line [Line] yaitu /L/ dan satu kata utuh yaitu [Shop] yang jika digabungkan akan menjadi [OLShop].

\section{Adopsi Bentuk, Makna, dan Tujuan Penggunaan (Akronim)}

\#fyi

Pada tahap peminjaman, \#fyidapat diperhatikan melalui wujud susunan bunyinya. \#fyi dalam bahasa Inggris memiliki pelafalan bunyi yang dieja perhuruf $\left[{ }^{\mathrm{e}} \mathrm{f} /{ }^{\mathrm{wa}} \mathrm{y} /{ }^{\mathrm{a}} \mathrm{i}\right]$, kemudian dipinjam langsung ke dalam susunan bunyi bahasa Indonesia dan dilafalkan menyerupai sebuah kata [fyi] menjadi [fiy]. Perubahan bunyi ini mengalami proses metatesis yang terlihat ketika fonem /I/ dan /Y/ ketika dilafalkan dalam bahasa Indonesia saling bertukar tempat. Penulisannya adalah [fyi] namun ketika diucapakan oleh masyarakat khususnya remaja Indonesia, bunyi /I/ berpindah ketengah kata dan bunyi /Y/ berpindah ke akhir kata menjadi [fiy], namun secara penulisan tetap [fyi]. /F/ adalah kosonan oral (labio-dental) yaitu konsonan yang dihasilkan dengan membuat bibir bawah menyentuh gigi atas, bertemu dengan konsonan oral (lamino-palatal) diakhiri dengan vokal agak tinggi tak bulat yaitu /I/. Pada tahap terjemahan pinjaman, \#fyi dalam bahasa Inggris memiliki makna "Informasi untuk kamu", dan ketika digunakan dalam bahasa Indonesia \#fyi tidak mengalami perubahan makna maupun perubahan tujuan penggunaan, hal ini karena \#fyi memiliki makna asosiatif yang ketika diciptakan telah ditentukan konsep dan tujuan pengunaannya.

Pada tahap ini, \#fyi dapat dijabarkan sebagai berikut: $\left[\frac{\text { For }}{1}+\frac{Y o u}{2}+\frac{\text { Information }}{2}\right]$. For bermakna untuk; You bermakna kamu. Namun You dalam \#fyi merujuk pada kepemilikan seseorang, oleh karena itu \#fyi ketika diucapkan secara kata per kata oleh 
remaja Indonesia kata You ditambahkan dengan kata bantu are menjadi You are dan jika digabungkan menjadi Your; Information bermakna keterangan atau informasi. Jika ditelusuri lebih jauh, Information merupakan frasa dari kata Inform dan sufiks -tion. Namun jika dilihat dari segi makna, Inform bermakna memberitahukan, sedangkan Information bermakna informasi atau keterangan, dalam hal ini \#fyi menempatkan sebuah informasi sebagai objek utama pembahasan, dan objek tersebut harusberasal dari kelas kata nomina, dan kata Information merupakan kata nomina. Maka dipilih kata Information sebagai bagian dari \#fyi. Proses compounding dalam hal ini menyangkut penyatuan makna [1][2][3] menjadi makna yang lebih sempit yaitu "Informasi untukmu" dan tidak mengalami perubahan makna atau tujuan ketika digunakan oleh masyarakat Indonesia sebab \#fyi memiliki makna asosiatif. \#fyi dalam bahasa Inggris termasuk dalam kelas kata verba khususnya verba desideratif yaitu verba yang menyatakan keinginan untuk melaksanakan perbuatan, dan ketika digunakan dalam bahasa Indonesia, \#fyi tidak mengalami perubahan kelas kata.

Tahap akronim yaitu proses pembentukan kata dengan mengambil huruf awal dari sebuah kata (Oktavia, 2017). Pada tahap akronim, \#fyi terdiri dari tiga kata yang diambil setiap huruf awalnya kemudian digabungkan menjadi satu kata dengan tujuan mempermudah pengucapan dan memperjelas makna. Prosesnya adalah sebagai berikut: Fer[1] $\rightarrow / \mathrm{F} /$; Yeu[2] $\rightarrow / \mathrm{Y} /$; Information[3] $\rightarrow / \mathrm{I} /$. Meski penggunaan \#fyi dalam bahasa Inggris dilafalkan perhuruf, namun ketika digunakan oleh masyarakat Indonesia khususnya kalangan remaja, \#fyi dilafalkan seperti sebuah kata.

\section{Adopsi Bentuk, Makna, dan Tujuan Penggunaan (Kata Utuh + Pelesapan Kata) \#typo}

Pada tahap peminjaman, \#typo mengalami 2 proses yaitu aferesis dan apokop. Proses aferesis terlihat ketika bunyi /a/ yang terdapat pada awal kata [ $\mathrm{t}^{\mathrm{a}} \mathrm{ypo}^{\mathrm{w}}$ ] dihilangkan sehingga menjadi [typo ${ }^{\mathrm{w}}$ ]. Proses apokop dalam hal ini terlihat ketika bunyi /w/ yang terdapat pada akhir kata $\left[\right.$ typo $^{\mathrm{w}}$ ] dihilangkan sehingga menjadi [typo]. /T/ merupakan konsonan oral (apiko-dental) yaitu konsonan yang dihasilkan dengan meletakan ujung lidah pada gigi atas, lalu disambung dengan konsonan oral (laminopalatal) yaitu /Y/, dilanjutkan dengan konsonan oral (bilabial) yaitu /P/ dan diakhiri dengan vokal tengah belakang bulat yaitu /O/. 
Pada tahap terjemahan pinjaman,\#typo memiliki makna harfiah "bentuk ejaan yang salah". Makna tersebut merujuk pada pemberitahuan kepada orang lain bahwa apa yang ditulis sebelumnya mengalami kesalahan dalam hal penulisan baik pada caption maupun komentar, dan kesalahan ejaan yang dimaksud adalah ejaan huruf maupun susunan kata dan tidak mengalami perubahan makna dan tujuan penggunannya ketika digunakan dalam bahasa Indonesia, hal ini karena \#typo memiliki makna asosiatif yang ketika diciptakan telah ditentukan konsep dan tujuan pengunaannya. Makna asosiatif adalah makna yang dimiliki sebuah kata berkenaan dengan hubungan kata itu dengan sesuatu yang berada di luar bahasa (Chaer, 2015). Makna asosiatif pada \#typo menandakan adanya pemberitahuan oleh seseorang bahwa dia telah melakukan kesalahan dalam hal pengetikan dan dia ingin memperbaikinya.

Tahap penggabungan pada \#typo dapat dijabarkan sebagai berikut: $\left[\frac{\text { Typographical }}{1}+\frac{\text { Error }}{2}\right]$. Typographical jika ditelusuri lebih dalam, merupakan frasa dari kata Typo dan Graphical.Typo bermakna kesalahan cetak, Graphical bermakna bentuk penulisan. Jadi sebenarnya Typo adalah kata yang diambil secara utuh sebab tidak mengalami pemotongan.Penambahan kata Graphical bertujuan untuk menjelaskan bahwa kesalahan cetak yang dimaksud adalah kesalahan penulisan huruf maupun susunan kata.Error bermakna kesalahan. Error memiliki fungsi yang sama dengan Graphical yaitu sebagai penjelas dari kata sebelumnya dan juga bertugas untuk mempertegas makna. Jika dilihat dari penulisan \#typo, Error dan Graphical tidak diwakili oleh huruf manapun, namun ketika \#typo dijabarkan, maka kata Graphical dan Error akan muncul untuk memperjelas dan mempertegas makna. Dalam bahasa Indonesia, \#typo sebenarnya sudah memiliki bentuk baku yang telah dimasukan dalam Kamus Besar Bahasa Indonesia menjadi TIPO.

Pembakuan ini mengalami proses netralisasi dalam bentuk pengucapan maupun penulisan. Proses netralisasi dalam hal ini terlihat ketika fonem /Y/ yang dilafalkan sebagai fonem /I/. Perubahan pelafalan ini disebabkan ketika orang Indonesia mendengar orang asing mengucapkan kata \#typo dengan pelafalan [ $\mathrm{t}^{\mathrm{a}} \mathrm{ypo}$, maka orang Indonesia, menyangka bahwa huruf /Y/ adalah huruf /I/, sebab sebelum huruf /Y/ terdengar bunyi $/ \mathrm{A} / \rightarrow /^{\mathrm{A}} \mathrm{Y} /$ yang jika dilihat dari susunan abjad dalam bahasa Inggris, bunyi / ${ }^{A} \mathrm{Y} /$ adalah pelafalan dari huruf /I/. Untuk itu [typo] akhirnya diadaptasi 
penulisan dan pengucapannya dalam bahasa Indonesia menjadi [tipo], tetapi secara makna dan arti, tipo diadopsi.

\section{Proses Adaptasi}

\section{Adaptasi Ucapan, Makna, dan Kelas Kata (KVK \& KVKV)}

\#lol

Pada tahap peminjaman, \#lol mengalami 1 proses, yaitu sinkop. Proses sinkopterlihat ketika bunyi /w/ yang terdengar setelah bunyi /o/ pada [1o $\left.{ }^{\underline{w}} 1\right]$ ditanggalkan dan menjadi [lol]. Proses penanggalan ini terjadi sebagai bentuk penyesuaian dengan ejaan bahasa Indonesia. Pada bahasa Inggris huruf /o/ mendapat tambahan bunyi /w/ setelahnya dan menjadi $/ 0^{\mathrm{w}} /$, namun dalam bahasa Indonesia huruf /o/ tidak mengalami perubahan bunyi, untuk itu bunyi /w/ dihilangkan sebab harus disesuaikan dengan kaidah bahasa Indonesia. /L/ merupakan konsonan oral (apikoalveolar) yaitu konsonan yang dihasilkan dengan meletakan ujung lidah pada gusi atas lalu bertemu dengan vokal tengah belakang bulat /O/ dan diakhiri lagi dengan konsonan oral (apiko-alveolar) /L/.

Pada tahap terjemahan pinjaman, [lol] dalam bahasa Inggris memiliki makna "tertawa terbahak-bahak" atau "tertawa dengan keras" kemudian berubah makna terjemahannya menjadi "merasa lucu" atau "lucu" dalam bahasa Indonesia. Perubahan makna ini terjadi karena adanya perkembangan sosial budaya. Perubahan makna ini terjadi sebab pengguna bahasa tersebut memiliki persepktif yang berbeda mengenai kata tersebut terjadi pada kata \#lol. Ketika terjadi perbedaan persepktif, maknanya pun akan mengalami perubahan.

Pada tahap ini, \#lol yang memiliki struktur kata KVK yang dapat dijabarkan sebagai berikut: $\left[\frac{\text { Laugh }}{1}+\frac{\text { out }}{2}+\frac{\text { Loud }}{3}\right]$. Laugh [1] bermakna tertawa; Out [2] bermakna benar-benar; Loud [3] bermakna keras. Proses compounding dalam hal ini menyangkut pada proses penyatuan makna [1] [2] [3] menjadi tunggal semantik "tertawa" atau "lucu". Proses penyatuan makna ini dapat dikatakan mengalami perluasan makna, karena dalam hal ini \#lol padabahasa Indonesia memiliki makna kontekstual. Artinya makna "tertawa" atau "lucu" dari kata \#lol bisa mengenai hal apa saja. Bisa saja bermakna "tertawa" atau "lucu" yang sesuai harfiah, atau bermakna sindiran, atau bermakna yang lain. Hal ini karena pendistribuasiannya belum jelas dan tergantung pada objek maupun konsep yang diwakili. [lol] ketika digunakan dalam bahasa Inggris 
termasuk kelas kata verba telis (kerja tuntas), dan ketika digunakan oleh remaja Indonesia, kelas kata \#lol berubah menjadi ajektifa (keadaan).

Tahap akronim (acronym) proses pembentukan kata dengan mengambil huruf awal dari sebuah kata (Oktavia, 2017). \#lol adalah gabungan dari tiga kata, lalu diambil huruf awal dari setiap kata dan digabungkan menjadi satu dengan tujuan untuk mempermudah pengucapan dan memperjelas makna, prosesnya adalah sebagai berikut: Laugh $[1] \rightarrow / \mathrm{L} /$, Out[2] $\rightarrow / \mathrm{O} /$, Leud[3] $\rightarrow / \mathrm{L} /$, dan jika digabungkan akan menjadi [lol]. Proses adaptasi terjadi karena menyesuaikan dengan konteks sosial masyarakat Indonesia. Hal ini sejalan dengan pendapat Putra, dkk (2015) latar belakang penggunaan kata serapan adalah kedekatan dengan masyarakat yakni memudahkan masyarakat dalam berkomunikasi.

\section{Adaptasi Ucapan, Makna, dan Kelas Kata (KKVK + Pelesapan Kata)}

\section{\#swag}

Pada tahap peminjaman, \#swag mengalami 2 proses, yaitu sinkop dan netralisasi. Proses sinkop terlihat ketika bunyi /w/ dan /a/ pada $\left[\mathrm{s}^{\mathrm{u}} \underline{\mathrm{wa}} \mathrm{e} g\right.$ ] ditanggalkan sehingga menjadi $\left[\mathrm{s}^{\mathrm{ue}} \mathrm{g}\right.$ ]. Pada proses netralisasi dalam hal ini terlihat ketika fonem $/ \mathrm{g} /$ dalam [s $\left.{ }^{\text {ue }} \mathrm{g}\right]$ dilafalkan seperti fonem $/ \mathrm{k} /$ menjadi $\left[\mathrm{s}^{\mathrm{ue}} \mathrm{k}\right]$. Pada tahap terjemahan pinjaman, \#swag ketika digunakan dalam bahasa Inggris memiliki makna "bergaya seperti gengster", kemudian berubah makna terjemahan menjadi "keren" ketika digunakan dalam bahasa Indonesia. Perubahan makna ini terjadi karena pengguna bahasa tersebut memiliki persepktif yang berbeda mengenai makna dari kata \#swag. Ketika terjadi perbedaan persepktif oleh masyarakat pengguna, maknanya pun akan mengalami perubahan.

Pada tahap ini, \#swag dapat dijabarkan sebagai berikut $\left[\frac{\text { Style }}{1}+\frac{\text { With }}{2}+\frac{A}{3}+\right.$ $\left.\frac{\text { little }}{-}+\frac{\text { Gangsta }}{4}\right]$. Style [1] bermakna "gaya"; With [2] bermakna "dengan"; A [3] bermakna "seorang"; little [-] bermakna "sedikit"; dan Gangsta [4] berasal dari kata gangsteryang bermakna "penjahat". Proses compounding dalam hal ini menyangkut pada proses penyatuan makna [1] [2] [3] [-] [4] menjadi tunggal semantik "keren" atau “mengagumkan". Proses penyatuan makna ini dapat dikatakan mengalami perluasan makna dalam hal ini \#swag dalam bahasa Indonesia memiliki makna kontekstual. Artinya makna "keren" dari kata \#swag bisa mengenai hal apa saja. Dapat bermakna "keren" yang sesuai harfiah atau bermakna sindiran atau bermakna yang lain. Hal ini 
karena pendistribuasiannya belum jelas dan tergantung pada objek maupun konsep yang diwakili.

\#swag dalam bahasa Inggris tergolong dalam kelas verba ekuatif yaitu verba yang mengungkapan ciri dari salah satu argumennya, dan ketika digunakan dalam bahasa Indonesia berubah kelas kata menjadi ajektifa. Perubahan kelas kata ini juga merupakan dampak dari berubahnya makna kata karena \#swag adalah kata yang memiliki makna kontekstual. Tahap akronim (acronym) yaitu proses pembentukan kata dengan mengambil huruf awal dari sebuah kata (Oktavia, 2017). \#swag adalah gabungan dari empat kata yang diambil huruf depannya kemudian digabungkan satu sama lain dengan tujuan untuk mempermudah pengucapan dan memperjelas makna, prosesnya adalah sebagai berikut: $S$ fe[1] $\rightarrow / \mathrm{S} /$, With [2] $\rightarrow / \mathrm{W} /, A$ [3] $\rightarrow / \mathrm{A} /$, titte[-] $\rightarrow$ /-/, Gengsta[4] $\rightarrow /$ G/ yang jika digabungkan huruf awal dari setiap kata akan menjadi \#swag. Proses akronim pada \#swag tergolong unik, karena kata little tidak diambil huruf depannya untuk kemudian digabungkan dengan huruf depan dari kata yang lain karena kata little. mengalami proses pelesapan. Namun ketika \#swag dijabarkan, kata little tetap ada dengan tujuan untuk memperjelas dan mempertegas makna \#swag secara keselurahn. Alasan mengapa little dilesapkan adalah karena ketika kata little (huruf awal kata little yaitu 1) digabungkan dengan\#swag akan menjadi \#swalg, meskipun dapat dibaca seperti sebuah kata, namun \#swalg dari segi penulisan dan pengucapan tidak menarik.

Adaptasi dalam konteks ini tidak hanya berkaitan dengan pendekatan komunikatif yakni memudakan khayalak menggunakan instagram, tetapi juga berkaitan dengan budaya. Hal ini relevan dengan pendapat Mukhibat (2015) pengaruh bahasa lain ke bahasa tertentu merupakan difusi dan akulturasi budaya, pengaruh tersebut terlihat pada kosakata yang diambil oleh bahasa tertentu.

\section{SIMPULAN}

Berdasarkan hasil dan pembahasan proses pembentukan kosakata baru sebagai bentuk coinage pada media sosial Instagram melalui proses adopsi dan adaptasi, terdapat sembilan proses. Proses adopsi memiliki tujuh proses diantaranya: (1) Adopsi bentuk, makna dan tujuan penggunaan (vokal tunggal + dua kata). (2) Adopsi bentuk, makna, dan tujuan penggunaan (vokal rangkap + dua kata). (3) Adopsi bentuk, makna, 
dan tujuan penggunaan (vokal rangkap + tiga kata). (4) Adopsi bentuk, makna, dan tujuan penggunaan (dua kata). (5) Adopsi bentuk, makna, dan tujuan penggunaan (tiga kata). (6) Adopsi bentuk, makna, dan tujuan penggunaan (akronim), (7) Adopsi bentuk, makna, dan tujuan penggunaan (kata utuh + pelesapan kata).

Proses adaptasi terdapat dua proses, diantarnya: (1) Adaptasi ucapan, makna, dan kelas kata (KVK \& KVKV). (2) Adaptasi ucapan, makna, dan kelas kata (KKVK + pelesapan kata). Data yang termasuk dalam proses adopsi adalah \#Instago, \#Instagood, \#Instafood, \#Instamood, \#instacool, \#Instapic, \#Instadailypic, \#diy, \#fyi, \#qotd, \#imho, \#rotfl, \#typo, \#OLShop. Sedangkan data yang termasuk dalam proses adaptasi adalah \#yolo, \#rip, \#lol, \#kepo, \#pap, \#swag.

\section{DAFTAR PUSTAKA}

Afjalurrahmansyah. (2018). Bahasa Arab dalam Bahasa Indonesia (Analisis Kritis terhadap Perubahan Makna Kata Serapan Bahasa Arab). Jurnal Diwan. 4 (1)

Chaer, Abdul. (2015). Morfologi Bahasa Indonesia (Pendekatan Proses). Rineka Cipta: Jakarta.

Dewi, Luh Putu Laksmi Prema. (2015). Type Of Word Formations On Instagram Hashtags. Universitas Udayana: Dempasar.

Jacobs, Stevani Wasti Philips. (2013). Penggunaan Pembentukan Kata Bahasa Inggris dalam Facebook. Universitas Sam Ratulangi: Manado.

Mukhibat. (2015). Analisis Semi-Historis Unsur-Unsur Bahasa Arab dalam Bahasa Indonesia. Jurnal Cendekia 13 (2)

Oktavia, Febri. (2017). An Analysis of Word Formation Processes of Slang Words in "the Beginning" Album by Black Eyed Peas. STKIP PGRI Sumatera Barat: Padang.

Putra, Dony Suryodi. (2015). Kata Serapan pada Kolom Iki Lho di Harian Joglosemar (Pola dan Latar Belakang Penggunaan. Jurnal BASASTRA Penelitian Bahasa, Sastra Indonesia dan Pengajarannya. 3 (3).

Sumarsono. (2012). Sosiolinguistik. Pustaka Pelajar: Yogyakarta.

Zubaidah, Siti. (2015). An Alaysis of Word Formation Process in Everday Communication on Facebook. Universiti Kebangsaan Malaysia: Malaysia. 